\title{
ARAŞTIRMA / RESEARCH \\ Perilipin-5 as a potential new biomarker in patients with liver disease and impaired De Ritis ratio
}

Karaciğer hastalığı ve bozulmuş De Ritis oranı olan hastalarda potansiyel yeni bir biyobelirteç olarak perilipin-5

İbrahim Ethem Şahin1 (D), Ceyhan Hacıoğlu1D, Fatih Davran1 (D), Merve Alpay1 (D)

${ }^{1}$ Düzce University, Department of Medical Biochemistry, Düzce, Turkey

Cukurova Medical Journal 2021;46(4)::1321-1326

\section{Abstract}

Purpose: Liver dysfunctions are one of the most prevalent and deadly diseases worldwide. The De Ritis ratio, which is obtained by proportioning serum aspartate aminotransferase (AST) and serum alanine aminotransferase (ALT), has been suggested to be a precious marker to assess the prognosis of liver diseases. This study was to investigate the relationship between perilipin 5 (PLIN5) levels and De Ritis ratio in patients with liver disease.

Materials and Methods: There were 3 groups: control (Group1; $n=20$ ), hepatic patients with normal De Ritis ratio (Group2; $n=35$ ) and hepatic patients with impaired De Ritis ratio (Group3; $n=35$ ). De Ritis rates of all patients were determined according to the serum aspartate aminotransferase (AST)/serum alanine aminotransferase (ALT) results. Additionally, PLIN5 was spectrophotometrically analyzed from serum samples.

Results: There is no significant difference between the groups in terms of age and gender. PLIN5 levels increased by 2.6 and 3.8 times in Group2 and Group3, respectively. De Ritis ratio was significantly increased in the Group3 compared the control, and enhanced PLIN5 levels was correlated with De Ritis ratio in the Group3. There was a significant positive correlation between De Ritis ratio and PLIN5 levels.

Conclusion: PLIN5 levels together with De Ritis rate in liver patients may be used as a prognostic marker. Furthermore, this relationship could be a useful method in the follow-up of liver diseases.

Keywords:. De Ritis ratio, Perilipin5, Liver damage, AST, ALT

\section{$\ddot{\mathrm{O} z}$}

Amaç: Karaciğer fonksiyon bozuklukları dünya çapında en yaygın ve ölümcül hastalıklardan biridir. Serum aspartat aminotransferaz (AST) ve serum alanin aminotransferazin (ALT) oranlanmasıyla elde edilen De Ritis oranının, karaciğer hastalıklarının prognozunu değerlendirmek için değerli bir belirteç olduğu öne sürülmüștür. Bu çalıșma, karaciğer hastalığ1 olan hastalarda perilipin 5 (PLIN5) düzeyleri ile De Ritis oranı arasındaki ilişkiyi araştırmak amacıyla yapılmıştır.

Gereç ve Yöntem: Kontrol (Grup1; $n=20)$, normal De Ritis oranı olan karaciğer hastaları (Grup2; $n=35)$ ve De Ritis oranı bozulmuş karaciğer hastaları (Grup3; n=35) olmak üzere 3 grup vardı. Tüm hastaların De Ritis oranları serum aspartat aminotransferaz (AST) / serum alanin aminotransferaz (ALT) sonuçlarına göre belirlendi. Ek olarak, PLIN5, serum örneklerinden spektrofotometrik olarak analiz edildi.

Bulgular: Gruplar arasında yaş ve cinsiyet açısından anlaml fark yoktu. PLIN5 seviyeleri Grup2 ve Grup3'te sirasıyla 2,6 ve 3,8 kat arttı. De Ritis oranı, kontrole kiyasla Grup3'te önemli ölçüde arttı ve artan PLIN5 seviyeleri, Grup3'teki De Ritis oranı ile korele idi. De Ritis oranı ile PLIN5 seviyeleri arasında anlamlı pozitif korelasyon vardı. Sonuç: Karaciğer hastalarında De Ritis oranı ile birlikte PLIN5 düzeyleri, prognostik bir belirteç olarak kullanılabilir. Ayrıca bu ilişki karaciğger hastalıklarının takibinde faydalı bir yöntem olabilir.

Anahtar kelimeler: De Ritis oran1, Perilipin5, Karaciğer hasar1, AST, ALT

Yazışma Adresi/Address for Correspondence: Dr. Ceyhan Hacıŏlu, Düzce University, Department of Medical Biochemistry, Düzce, Turkey E-mail: ceyhanhacioglu@duzce.edu.tr

Geliş tarihi/Received: 29.07.2021 Kabul tarihi/Accepted: 09.09.2021 Çevrimiçi yayın/Published online: 17.09.2021 


\section{INTRODUCTION}

The liver has a key role in several metabolic and regulatory pathways. For example, it includes the fuel metabolism, bile synthesis and excretion, synthesis of many plasma proteins including albumin, fibrinogen and prothrombin as well as storage of vitamins and detoxification of xenobiotics ${ }^{1}$. The liver, as a large organ, performs its functions with extensive reserve capacity. Despite hepatocellular damage, the liver can maintain normal functions ${ }^{2}$. In such cases, liver function tests are useful in identifying and monitoring the disease ${ }^{3}$. It is commonly accomplished by measuring plasma activities of enzymes found in liver cells and secreted into the blood in different cell damage situations. For example, the type and degree of elevation of enzyme activity vary according to the type of liver cell damage; their measurement is extremely helpful in recognizing and diagnosing damage ${ }^{4}$.

The determination of the activity of serum aspartate transaminase (AST, EC 2.6.1.1) and serum alanine transaminase enzymes (ALT, EC 2.6.1.2) has a major role in the evaluation of liver injury. ALT is found in various tissues, but plasma activities mainly reflect liver damage. AST is found in the liver, muscle and limited levels in erythrocytes. Therefore, based on tissue distribution, ALT is considered being a favorable biomarker for determining the state of liver disease $^{5}$. Although AST and ALT enzymes have cytosolic and mitochondrial isoenzymes in the liver, the mitochondrial isoenzyme of ALT is lower. The half-life of the mitochondrial isoenzyme of ALT is very short and its clinical diagnostic value is insignificant. The mitochondrial isoenzyme of AST is an important part of the total amount in hepatocytes ${ }^{6}$.

Serum AST and ALT ratio were defined by De Ritis and colleagues as the De Ritis ratio. In the event of any liver injury, the AST and ALT levels in the blood increase as the membrane integrity of the hepatocytes deteriorate. It was confirmed that abnormal differences in De Ritis (AST/ALT) rate have been described as an indicator of liver damage 7 . This ratio is particularly useful for distinguishing hepatic lesions (De Ritis ratio $<0.7$ and $>1.5$ ) and extra hepatic lesions (De Ritis ratio $>1.5$ ). The ratio of De Ritis for a normal individual proposed by the International Federation of Clinical Chemistry (IFCC) is between 0.7 and $1.4^{8}$. De Ritis ratio is $\leq 1$ in most viral hepatitis and acute hepatocellular diseases. However, the rate of De Ritis in chronic liver diseases such as cirrhosis is $>1$. Besides, De Ritis ratio $>2$ and $>3$ indicate a high rate of alcoholic liver disease?

The perilipin family (PLIN1-5) is a group of proteins associated with lipid droplets (LD) consisting of a single layer of phospholipids, free cholesterol and nuclei of neutral lipids coated by specific proteins, which modulate lipid homeostasis by regulating intracellular energy metabolism in many eukaryotic cells ${ }^{10}$. Perilipin-5 (PLIN5), which is important for the accumulation and hydrolysis of triacylglycerol (TAG), is a $51 \mathrm{kDa}$ molecular weight cytosolic LD protein that is highly expressed in tissues with predominant oxidative metabolisms such as heart, skeletal muscle and liver ${ }^{11}$. Although the function of PLIN5 is not well defined, especially in humans, evidence from recent studies has been reported that PLIN5 expression can be regulated by cellular triglyceride content in parallel with the increase of fatty acid (FA) oxidation with enhanced oxidative metabolism ${ }^{12}$. PLIN5, which is usually found in tissues/cells using lipids for energy through mitochondrial $\beta$-oxidation, has an important act in intracellular transport in hepatocytes, in coordinating intracellular signaling and organization ${ }^{13}$. Previous studies were focused on the function of PLIN5 in protecting hepatocytes against lipotoxic damage and preventing the oxidative burden of the heart ${ }^{14}$. It was suggested that the physiological role of PLIN5 in human muscle tissue could play a protective role against lipotoxicity by promoting interaction with $\mathrm{LDs}^{15}$. Furthermore, it was reported that the expression of PLIN5 is significantly increased in the case of hepatic steatosis due to adenoviral-mediated increased lipid accumulation in the liver ${ }^{16}$. However, it is not yet known whether PLIN5 levels may have a role in the diagnosis, clinical features and prognosis of liver injury cases. Therefore, in the study, we demonstrated a positive correlation between serum PLIN5 levels in humans and the De Ritis rate, an important indicator of liver damage.

\section{MATERIALS AND METHODS}

\section{Study design and participants}

The study consists of participants who applied to the internal medicine outpatient clinic of Duzce University Research Hospital between May 2019 and January 2020 for routine controls or liver disease. The study was conducted in 90 subjects, 42 females and 48 males, ranging in age from 30 to 69 years. The subjects were divided into three groups: Group 1 
(control; healthy individuals, $\mathrm{n}=20$ ), Group 2 (patients with normal De Ritis ratio, $n=35$ ), Group 3 (patients with impaired De Ritis ratio, $n=35$ ).

Subjects in the control group were selected from healthy individuals who did not drink alcohol, did not smoke, and had normal liver function tests. Although liver function tests were normal, people who smoke or drink alcohol, and those with any acute or chronic diseases such as heart, muscle and kidney disease were not included in the control group. Exclusion criteria in patient groups: patients with thyroid, heart, muscle and kidney disease, cancer, diabetes and hypertension were not included in the study. The subjects in the patient groups were selected only from people with liver disease.

All patients in Group 2 and Group 3 were firstly diagnosed with liver diseases such as alcoholic liver disease, chronic hepatitis, abnormal liver function tests, viral hepatitis and non-alcoholic fatty liver disease. Blood samples were taken from these patients who applied to the internal medicine outpatient clinic for the first time before starting any drug treatment. Patients with any heart and muscle problems or complaints were excluded from the study.

Blood samples were taken from subjects who were fasting for up to $12 \mathrm{~h}$ because fasting regulates the subcellular organization of PLIN5 and increase its expression $^{15}$. Demographic characteristics and laboratory data for all groups are summarized in Table 1. PLIN5 levels were measured to be $0.073 \pm$ 0.015 in healthy individuals as a result of a preliminary study with 10 individuals. It was calculated that a minimum of 18 individuals in each group should be taken with $80 \%$ power and 5\% type I error in order to determine the statistical significance of $1 \mathrm{sd}$ difference between the groups.

All aspects of the study were conducted in accordance with the Helsinki Declaration and approved by the Clinical Research Ethics Committee of Duzce University (Decision No: 2019/33 and Date: 04.03.2019). All subjects were informed verbally and in writing about the experimental design and possible risks and voluntarily included in the study. Informed consent was obtained from each patient included in the study.

\section{Biochemical analysis}

Blood samples were centrifuged at $3000 \mathrm{xg}$ for 15 minutes and the serums were stored at $-80^{\circ} \mathrm{C}$ until the day of analysis. Serum levels of PLIN5 were determined by commercially available ELISA kit (Human SEE039Hu, Uscn Life Science Inc., USA) according to the manufacturer's instructions. The results were expressed as $n g / \mathrm{mL}$. De Ritis rate of the subjects was determined by proportioning AST and ALT values measured from serum samples. Additionally, serum lipid profile [total cholesterol, high-density lipoprotein cholesterol (HDL-C), lowdensity lipoprotein cholesterol (LDL-C) and triglycerides], AST and ALT levels were analyzed by auto-analyzer within 1 hour following taken blood samples centrifuged at $4^{\circ} \mathrm{C} 3000 \mathrm{xg}$ for 15 minutes.

\section{Statistical analysis}

Results were reported as mean \pm standard deviation (SD). All statistical analyzes were performed using GraphPad Prism 7 (San Diego, CA). Shapiro-Wilks test was used to test whether the distribution of the quantitative variables analyzed deviated from normality. Descriptive statistics of patient demographic categorical variables such gender and ages across three groups of subjects were compared using the Chi-square test. For all other variables in Table 1 continues variables showing normal distribution were analyzed using One-Way ANOVA followed by a post hoc Tukey test was performed for multiple comparisons. $\mathrm{P}<0.05$ values were taken as significant.

\section{RESULTS}

The clinical and biochemical characteristics of the subjects are shown in Table 1 . A total of 90 subjects ( 48 male and 42 female) with a mean age of $51.3 \pm 5.18$ years were included in the study. Also, $77.7 \%$ of the patients were diagnosed with liver disease and 50\% of them had De Ritis rate outside the normal range (between 0.7 and 1.4). The 70 patients with liver disease, 20 had alcoholic liver disease, 13 had chronic hepatitis, 18 had abnormal liver function tests, 10 had viral hepatitis, and 9 had non-alcoholic fatty liver disease.

There was a statistically significant variation in total cholesterol, LDL, triglycerides, GGT, AST, ALT, De Ritis ratio and PLIN5 between the three groups. Contrarily, there was no significant difference between the gender and HDL levels. Patients with liver disease showed an increase in LDL, triglyceride, AST, ALT and GGT levels compared to the control group ( $\mathrm{P}<0,0001)$. 
As shown in Figure 1, the serum PLIN5 levels were markedly higher in patients with the liver disease compared with the control $(P<0.001)$. Additionally, serum concentrations of PLIN5 were higher in the patients with impaired De Ritis ratio than in patients with normal De Ritis ratio $(P<0.001)$.

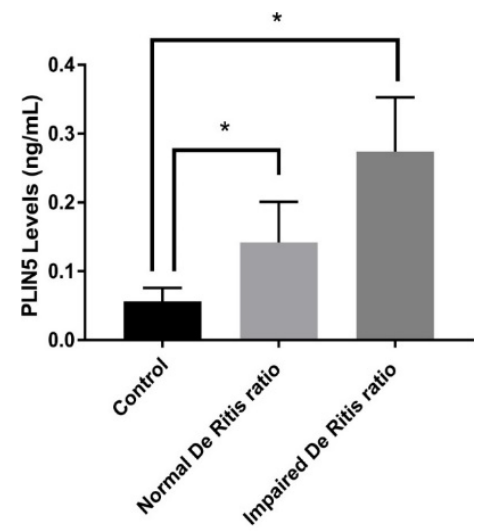

Figure 1. PLIN 5 levels in all groups.

$* P<0.001$, compared with control
Pearson Correlation test indicates positively a relationship between PLIN5 levels and De Ritis ratio (Figure 2). With $\mathrm{r}=0.806$ and $P<0.001$, the correlation was found to be statistically significant. Thence, it is deduced that the serum PLIN5 levels enhance with an increase in De Ritis ratio.

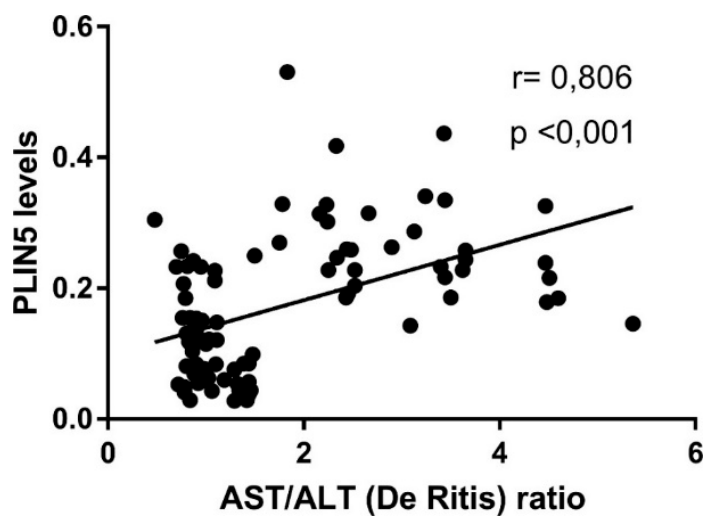

Figure 2. Correlation between PLIN5 levels and AST/ALT (De Ritis) ratio

Table 1. Basic and biochemical characteristics of the patients participating in the study

\begin{tabular}{|l|c|c|c|c|}
\hline & Control (n=20) & $\begin{array}{c}\text { Patients with } \\
\text { normal De Ritis } \\
\text { ratio (n=35) }\end{array}$ & $\begin{array}{c}\text { Patients with } \\
\text { impaired De Ritis ratio } \\
\mathbf{( n = 3 5 )}\end{array}$ & $\boldsymbol{P}$ \\
\hline Female & 12 & 16 & 14 & $0.356^{*}$ \\
\hline Male & 8 & 19 & 21 & $0.176^{*}$ \\
\hline Age & $41.6 \pm 9.61$ & $48.3 \pm 15.2$ & $50.7 \pm 12.8$ & $<0.0001$ \\
\hline Total cholesterol (mg/dL) & $105.8 \pm 31.9$ & $195.1 \pm 27.2$ & $254.9 \pm 42.6$ & 0.2962 \\
\hline HDL (mg/dL) & $39.4 \pm 8.2$ & $68.3 \pm 10.7$ & $56.9 \pm 9.4$ & $<0.0001$ \\
\hline LDL(mg/dL) & $65.1 \pm 12.8$ & $139.1 \pm 12.5$ & $170.2 \pm 24.6$ & $<0.0001$ \\
\hline Triglycerides (mg/dL) & $96.3 \pm 18.5$ & $214.8 \pm 10.7$ & $195.2 \pm 23.6$ & $<0.0001$ \\
\hline GGT (U/L) & $42.7 \pm 8.1$ & $112.5 \pm 36.8$ & $179.5 \pm 24.2$ & $<0.0001$ \\
\hline AST (U/L) & $24.6 \pm 8.1$ & $183.1 \pm 26.7$ & $291.6 \pm 50.9$ & $<0.0001$ \\
\hline ALT (U/L) & $21.9 \pm 5.3$ & $170.4 \pm 33.5$ & $142.5 \pm 22.6$ & $<0.0001$ \\
\hline De Ritis ratio (AST/ALT) & $0.96 \pm 0.16$ & $1.08 \pm 0.25$ & $2.15 \pm 0.42$ & \\
\hline
\end{tabular}

Chi-square test; HDL: high-density lipoprotein; LDL: low-density lipoprotein; AST: aspartate aminotransferase; ALT: alanine aminotransferase; GGT: gamma glutamyl transpeptidase

\section{DISCUSSION}

De Ritis ratio, defined by serum levels of aminotransferases, is a sensitive indicator in determining liver damage and prognosis ${ }^{7}$. It is clear that serum ALT and AST levels increase several-fold in liver diseases and the De Ritis ratio, which is normally between 0.7 and 1.4, falls below 1 . However, atypical cases suggest that acute viral hepatitis with a poor prognosis may occasionally cause an AST/ALT ratio of over $1.5^{17}$. In chronic viral hepatitis cases, the De Ritis ratios are generally below 1.0, but in cases of advanced cirrhosis, this ratio increases to 1.0. Also, increased serum GGT levels are among the important findings in advanced chronic viral hepatitis and hepatocellular carcinoma complications ${ }^{18}$. Researchers were noted that patients with alcoholic liver disease have De Ritis ratio over 1.5 ${ }^{19}$. Conversely, De Ritis ratio is less than 1.0 in 1 out of 3 patients with alcoholic liver disease. This 
situation was thought to be due to as the biased selection of patients participating in the studies or the AST half-life being shorter than the ALT half-life ${ }^{20}$. The prevalence of non-alcoholic fatty liver, which has been a general liver disease, exceeds $10 \%$ and De Ritis rate is less than 1 in these patients ${ }^{21}$. In parallel to the aforementioned data, De Ritis rates of patients with alcoholic liver disease, chronic hepatitis, abnormal liver function tests, viral hepatitis and non-alcoholic fatty liver disease were $<1$ in our study and accompanied by a nearly five-fold increase in GGT levels.

Lipid content and transaminase levels in liver tissue increased significantly in relation to the increased lipid content in the diet. The increased amount of lipids in the liver is also a characteristic of nonalcohol liver disease, which causes liver damage when improperly metabolized and during this condition, AST/ALT ratio is getting upregulated ${ }^{22}$.

The PLIN family is a representative group of LDassociated proteins and PLIN5 is important for accumulation and hydrolysis of triacylglycerol ${ }^{10}$. PLIN5 interacts with other molecules and organelles that control lipid homeostasis in cells to regulate cellular fuel metabolism, and controls the regulation of LDs and hydrolysis of FA ${ }^{11}$. Previous studies have shown that PLIN5 is an intracellular lipid storage droplet protein that protects against increased FA oxidation and lipotoxic damage due to increased use of FA in cancerous hepatocytes, skeletal muscle and cardiomyocytes $^{23}$. Our data showed that there may be a strong relationship between the rate of De Ritis, which is an important marker in liver disease, and the levels of PLIN5 released into circulation with damage to hepatocytes. It is conceivable to say that disrupted hepatocyte content through tissue damage may have caused increased levels of both transaminases and PLIN5 in the circulation.

PLIN5 protected against hepatic lipotoxic injury induced by liver enzymes. Previous studies have identified the change in lipoprotein amounts and liver enzymes as major risk factors for the prognosis of hepatic diseases ${ }^{24,25}$. Wang et al. reported that there was a decrease in hepatic lipid stores in PLIN5 null mice $^{13}$. They showed that increased hepatic lipolysis due to Plin5 deficiency induced lipotoxic liver damage by causing an increase in unesterified fatty acids (NEFAs) and an increase in NEFAs oxidation. Additionally, it was supported that liver-specific Plin5 deletion impairs glucose tolerance by reducing the effect of intrahepatic insulin and causes systemic insulin resistance ${ }^{24}$. This study indicated that PLIN5, one of the important mediators of hepatic lipid metabolism, suppressed liver damage by regulating insulin action in the liver. Recently, PLIN5 was shown to be locally over expressed in the hepatoma nodules areas, which are formed in hepatocellular carcinoma ${ }^{25}$. This study considers that PLIN5, which is responsible for the homeostasis of liver lipid metabolism, may have different uses from diagnosis to treatment. Thus, the increased expression of PLIN5 with tissue damage may explain its increased levels in the circulation. Consistent with the aforementioned studies, PLIN5 levels in serum may increase with De Ritis ratio in cases of liver pathology.

One of the important limitations of our study is the low sample size. In this study, generally all liver diseases were included in the study. Another important deficiency is that PLIN5 has not been specifically evaluated for each liver disease. Moreover, it was not known whether the subjects in the study followed a long-term diet.

To sum up, we sought an answer to the question whether PLIN5 released into the circulation due to hepatocyte damage in liver diseases would be valuable in the early stages or prognosis of the disease. In this study, we detected that PLIN5 levels in serum increased with the deteriorated De Ritis ratio. Moreover, we found a positive correlation between De Ritis ratio and PLIN5 levels. The results consider that PLIN5 increases in serum with liver tissue damage and may be a potential biomarker in the prognosis of liver diseases with the De Ritis ratio. Therefore, it needs more comprehensive molecular studies and should be investigated the effects of drugs on PLIN5 in the treatment of liver diseases.

\footnotetext{
Yazar Katkıları: Çalışma konsepti/Tasarımı: IEŞ, CH, FD, MA; Veri toplama: IESS, $\mathrm{CH}$; Veri analizi ve yorumlama: $\mathrm{CH}, \mathrm{MA}$; Yazı taslağ1: $\mathrm{CH}, \mathrm{MA}$; İçeriğin eleştirel incelenmesi: $\mathrm{CH}$; Son onay ve sorumluluk: IEŞ, CH, FD, MA; Teknik ve malzeme desteği: CH; Süpervizyon: IEŞ, $\mathrm{CH}$; Fon sağlama (mevcut ise): yok.

Etik Onay: Bu çalışma için Düzce Üniversitesi Klinik Araştırmalar Etik Kurulu tarafindan onaylandı (Karar No: 2019/33). Tüm hastalar yazılı bilgilendirilmiş onam verdi.

Hakem Değerlendirmesi: Dış bağımsız.

Çıkar Çatışması: Yazarlar çıkar çatışması bevan etmemișlerdir. Finansal Destek: Yazarlar finansal destek beyan etmemişlerdir.

Author Contributions: Concept/Design : İEŞ, CH, FD, MA; Data acquisition: : IEŞ, $\mathrm{CH}$; Data analysis and interpretation: $\mathrm{CH}, \mathrm{MA}$; Drafting manuscript: $\mathrm{CH}, \mathrm{MA}$; Critical revision of manuscript: $\mathrm{CH}$; Final approval and accountability: IES, CH, FD, MA; Technical or material support: $\mathrm{CH}$; Supervision: İES, $\mathrm{CH}$; Securing funding (if available): $\mathrm{n} / \mathrm{a}$.

Ethical Approval: The study protocol was approved by the Clinical Research Ethics Committee of Duzce University (Decision No: 2019/33 and Date: 04.03.2019). All patients provided written informed consent.
} 
Peer-review: Externally peer-reviewed.

Conflict of Interest: Authors declared no conflict of interest.

Financial Disclosure: Authors declared no financial support

\section{REFERENCES}

1. De Ritis F, Coltorti M, Giusti G. An enzymic test for the diagnosis of viral hepatitis: the transaminase serum activities. 1957. Clin Chim Acta. 2006;369:148-52.

2. Tao Y, Wang M, Chen E, Tang H. Liver regeneration: Analysis of the main relevant signaling molecules. Mediators Inflamm. 2017;2017:4256352.

3. Brenner C, Galluzzi L, Kepp O, Kroemer G. Decoding cell death signals in liver inflammation. J Hepatol. 2013;59:583-94.

4. Vagvala SH, O'Connor SD. Imaging of abnormal liver function tests. Clin Liver Dis (Hoboken). 2018;11:128-34.

5. Kwo PY, Cohen SM, Lim JK. ACG clinical guideline: Evaluation of abnormal liver chemistries. Am J Gastroenterol. 2017;112:18-35.

6. Zhou JH, Cai JJ, She ZG, Li HL. Noninvasive evaluation of nonalcoholic fatty liver disease: Current evidence and practice. World J Gastroenterol. 2019;25:1307-26.

7. Malakouti M, Kataria A, Ali SK, Schenker S. Elevated liver enzymes in asymptomatic patients - What should I do? J Clin Transl Hepatol. 2017;5:394-403.

8. Schumann G, Bonora R, Ceriotti F, Férard G, Ferrero CA, Franck PF et al. IFCC primary reference procedures for the measurement of catalytic activity concentrations of enzymes at 37 degrees C. International Federation of Clinical Chemistry and Laboratory Medicine. Part 4. Reference procedure for the measurement of catalytic concentration of alanine aminotransferase. Clin Chem Lab Med. 2002;40:71824.

9. Rekha M, Jayaprakash Murthy DS, Purnima RT, Dattatreya K. Evaluation of De Ritis ratio, alkaline phosphatase and bilirubin in liver diseases. J Pharm Sci Res. 2011;3:1096-102.

10. Xu S, Zhang X, Liu P. Lipid droplet proteins and metabolic diseases. Biochim Biophys Acta Mol Basis Dis. 2018;1864:1968-83.

11. Dalen KT, Dahl T, Holter E et al. LSDP5 is a PAT protein specifically expressed in fatty acid oxidizing tissues. Biochim Biophys Acta 2007;1771:210-27.

12. Trevino MB, Mazur-Hart D, Machida Y, Arntsen B, Londos C, Sztalryd C et al. Liver perilipin 5 expression worsens hepatosteatosis but not insulin resistance in high fat-fed mice. Mol Endocrinol. 2015;29:1414-25.
13. Wang C, Zhao Y, Gao X, Li L, Yuan Y, Liu F et al. Perilipin 5 improves hepatic lipotoxicity by inhibiting lipolysis. Hepatol. 2015;61:870-82.

14. Kuramoto K, Okamura T, Yamaguchi T, Nakamura TY, Wakabayashi S, Morinaga $\mathrm{H}$ et al. Perilipin 5, a lipid droplet-binding protein, protects heart from oxidative burden by sequestering fatty acid from excessive oxidation. J Biol Chem. 2012;287:23852-63.

15. Gemmink A, Bosma M, Kuijpers HJ, Hoeks J, Schaart $G$, van Zandvoort MA et al. Decoration of intramyocellular lipid droplets with PLIN5 modulates fasting-induced insulin resistance and lipotoxicity in humans. Diabetologia. 2016;59:1040-8.

16. Majhi S, Baral N, Lamsal M, Mehta KD. De Ritis ratio as diagnostic marker of alcoholic liver disease. Nepal Med Coll J. 2006;8:40-2.

17. Botros M, Sikaris KA, Lu ZX, McNeil A. The short term prognostic usefulness of the De Ritis ratio. Clin Biochem Rev. 2013;34:1-18.

18. McGill MR. The past and present of serum aminotransferases and the future of liver injury biomarkers. EXCLI J. 2016;15:817-28.

19. Hann HW, Wan S, Myers RE, Hann RS, Xing J, Chen $B$ et al. Comprehensive analysis of common serum liver enzymes as prospective predictors of hepatocellular carcinoma in HBV patients. PLoS One. 2012;7:e47687.

20. Kim E, Park SH. Diagnosis and severity assessment of alcohol-related liver disease. Korean J Gastroenterol. 2020;76:60-4.

21. Topic A, Djukic M. Diagnostic characteristics and application of alcohol biomarkers. Clin Lab. 2013;59:233-45.

22. Spreafico F, Sales RC, Gil-Zamorano J, Medeiros PDC, Latasa MJ, Lima MR et al. Dietary supplementation with hybrid palm oil alters liver function in the common Marmoset. Sci Rep. 2018;8:2765.

23. Kimmel AR, Brasaemle DL, McAndrews-Hill M, Sztalryd C, Londos C. Adoption of PERILIPIN as a unifying nomenclature for the mammalian PATfamily of intracellular lipid storage droplet proteins. J Lipid Res. 2010;51:468-71.

24. Keenan SN, Meex RC, Lo JCY, Ryan A, Nie S, Montgomery $\mathrm{MK}$ et al. Perilipin 5 deletion in hepatocytes remodels lipid metabolism and causes hepatic insulin resistance in mice. Diabetes. 2019;68:543-55.

25. Asimakopoulou A, Vucur M, Luedde T, Schneiders S, Kalampoka S, Weiss TS et al. Perilipin 5 and lipocalin 2 expression in hepatocellular carcinoma. Cancers (Basel). 2019;11:385. 